\title{
Characterization of MSlys, the endolysin of Streptococcus pneumoniae phage MS1
}

\author{
Maria Daniela Silva ${ }^{a}$, Hugo Oliveira ${ }^{a}$, Alberta Faustino ${ }^{\mathrm{b}}$, Sanna Sillankorva $^{\mathrm{c}, *}$ \\ ${ }^{a}$ CEB - Centre of Biological Engineering, LIBRO - Laboratório de Investigação em Biofilmes Rosário Oliveira, University of Minho, 4710-057 Braga, Portugal \\ ${ }^{\mathrm{b}}$ Clinical Pathology Department, Hospital de Braga, 4710-243 Braga, Portugal \\ c INL - International Iberian Nanotechnology Laboratory, Avenida Mestre José Veiga, 4715-330 Braga, Portugal
}

\section{A R T I C L E I N F O}

\section{Article history:}

Received 16 July 2020

Received in revised form 23 October 2020

Accepted 23 October 2020

\section{Keywords:}

Endolysin

Streptococcus pneumoniae

MSlys

Antibacterial

Biofilm

\begin{abstract}
A B S T R A C T
Despite the use of pneumococcal conjugate vaccines, the number of infections related to Streptococcus pneumoniae continues to be alarming.

Herein, we identified, characterized the MSlys endolysin encoded in the phage MS1. We further tested its antimicrobial efficacy against planktonic and biofilm cells, assessing the culturability of cells and biofilm structure by scanning electron microscopy, and confocal laser scanning microscopy.

The modular MSlys endolysin consists of an amidase catalytic domain and a choline-binding domain. MSlys is active against isolates of children with otitis media, and conditions close to those found in the middle ear. Treatment with MSlys ( $2 \mathrm{~h}, 4 \mu \mathrm{M})$ reduced planktonic cultures by $3.5 \log 10 \mathrm{CFU} / \mathrm{mL}$, and 24and 48-h-old biofilms by 1.5 and $1.8 \log 10 \mathrm{CFU} / \mathrm{mL}$, respectively. Imaging of the biofilms showed thinner and damaged structures compared to control samples.

The recombinantly expressed MSlys may be a suitable candidate for treating pneumococcal infections, including otitis media.
\end{abstract}

(C) 2020 The Authors. Published by Elsevier B.V. This is an open access article under the CC BY-NC-ND license (http://creativecommons.org/licenses/by-nc-nd/4.0/).

\section{Introduction}

S. pneumoniae is a common colonizer of the nasopharynx of healthy humans since early infancy [1]. It is also responsible for several infectious diseases such as otitis media and sinusitis, as well as life-threatening invasive diseases, including pneumonia, sepsis, and meningitis [1,2]. Despite the implementation of pneumococcal conjugate vaccines into national immunization programs, $S$. pneumoniae continues to be a common cause of morbidity and mortality worldwide [2], resulting in 1.6 million deaths every year [3].

Biofilms are communities of microorganisms embedded in a self-produced extracellular polymeric matrix and attached to a surface [4], being a common cause of persistent bacterial infections [5]. Growth in biofilms benefits bacteria protecting against environmental stresses, host immune defenses, as well as antimicrobial agents [4]. S. pneumoniae tolerates high antibiotic concentrations and belongs to the World Health Organization priority list of pathogens in need for R\&D of new antimicrobials [6].

$S$. pneumoniae phages, such as $\mathrm{Dp}-1$ and $\mathrm{Cp}-1$, have been isolated and thoroughly characterized. However, they do not infect

\footnotetext{
* Corresponding author.

E-mail address: sanna.sillankorva@inl.int (S. Sillankorva).
}

encapsulated pneumococcal strains, which are highly prevalent in disease, limiting phage therapeutic use [7]. More recently, phage MS1, which is related to the Dp-1 phage (average nucleotide identity of $73.3 \%$ on $62.3 \%$ of aligned nucleotides), was isolated [8]. Unlike phages, phage endolysins can effectively kill this pathogen. Shortly after the isolation of Dp- 1 and $\mathrm{Cp}-1$ phages, the lytic enzymes Pal and Cpl-1 were identified. Their ability to kill $S$. pneumoniae when applied exogenously was, later on, demonstrated when used alone [9], together [10], and even combined with antibiotics [11]. Their antibacterial potential in animal models mimicking nasopharyngeal colonization [9], bacteremia [12], endocarditis [13], otitis media [14], among others, provided excellent results.

Endolysins identified in pneumococcal phages and also many proteins found in the pneumococcal cell wall (e.g., LytA autolysin) are characterized by a modular organization. The $\mathrm{N}$ terminal of these is responsible for the catalytic activity and the Cterminal for the cell binding. This cell-binding domain is highly conserved (with the only natural exception being Cpl-7 from the Cp-7 phage), consisting of several choline-binding repeats that belong to the CW_binding_1 family and conferring specificity to these enzymes, which require the presence of choline in the cell wall teichoic acids for substrate recognition. Beyond the uniqueness, this characteristic makes the emergence of resistance negligible [15]. 
The work described herein focuses on the in silico identification, recombinant expression, and characterization of MSlys, a novel natural endolysin encoded in the pneumococcal phage MS1. Furthermore, its antibacterial activity against $S$. pneumoniae planktonic and biofilm cells, as well as its stability under different $\mathrm{pH}$ and temperature, was evaluated.

\section{Materials and methods}

2.1. Bacteria, phages, growth conditions, and plasmids

S. pneumoniae R6st was obtained from the Félix d'Hérelle Reference Center for Bacterial Viruses (Université Laval, Quebec,
Canada) along with phages Dp-1 and MS1. Different S. pneumoniae isolates and Streptococcus and non-streptococcal species were tested to determine the lytic spectrum of MSlys (Table 1 ). $S$. pneumoniae were grown at $37^{\circ} \mathrm{C}$ with $5 \% \mathrm{CO}_{2}$ in Todd Hewitt Broth (THB) supplemented with $2 \%(\mathrm{w} / \mathrm{v})$ yeast extract $\left(\mathrm{THB}_{\mathrm{ye}}\right)$ or in solid Tryptic Soy Broth (TSB) (TSB + $1.2 \%(\mathrm{w} / \mathrm{v})$ agar with $5 \%$ sheep blood) $\left(\mathrm{TSA}_{\mathrm{sb}}\right)$. H. influenzae was grown in Brain Heart Infusion Broth (BHI) supplemented with $10 \mu \mathrm{g} / \mathrm{mL}$ NAD (VWR) and $10 \mu \mathrm{g} / \mathrm{mL}$ Hemin $\left(\mathrm{BHI}_{\mathrm{NH}}, 37^{\circ} \mathrm{C}, 5 \% \mathrm{CO}_{2}\right)$. M. catarrhalis was grown in $\mathrm{BHI}\left(37^{\circ} \mathrm{C}, 5 \%\right.$ $\mathrm{CO}_{2}$ ), and $S$. aureus, $P$. aeruginosa, and $E$. faecalis were grown in TSB at $37{ }^{\circ} \mathrm{C}$ in aerobic conditions. Escherichia coli TOP10 and BL21(DE3) (Invitrogen, ThermoFisher Scientific) were grown in Lysogeny Broth (LB) in liquid or solid form $\left(1.2 \%(\mathrm{w} / \mathrm{v})\right.$ of agar) at $37^{\circ} \mathrm{C}$. The

Table 1

The spectrum of activity of MSlys.

\begin{tabular}{|c|c|c|c|c|}
\hline Species & Strain & Origin or Source & $\begin{array}{l}\text { Growth } \\
\text { conditions }\end{array}$ & $\begin{array}{l}\text { Endolysin } \\
\text { activity }\end{array}$ \\
\hline \multirow[t]{28}{*}{ Streptococcus pneumoniae } & R6st & Félix d’Hérelle Reference Center for Bacterial Viruses & \multirow[t]{28}{*}{$37{ }^{\circ} \mathrm{C}, 5 \% \mathrm{CO}_{2}$} & + \\
\hline & P046 & $\begin{array}{l}\text { CIBER de Enfermedades Respiratorias, Madrid, Spain - Centro de } \\
\text { Investigaciones Biológicas }\end{array}$ & & + \\
\hline & $\begin{array}{l}\text { MEF7_I1 (serotype } \\
6 \text { A/B) }\end{array}$ & Middle ear fluid of children with otitis media, Hospital de Braga & & + \\
\hline & MEF8_I2 & & & + \\
\hline & MEF12_I1 & & & + \\
\hline & MEF13_I1 & & & + \\
\hline & MEF14_I3 & & & + \\
\hline & MEF15_I3 (serotype & \multirow{8}{*}{$\begin{array}{l}\text { Middle ear fluid of children with otitis media, Trofa Saúde Hospital Braga } \\
\text { Sul }\end{array}$} & & + \\
\hline & $6 A / B)$ & & & \\
\hline & MEF16_I1 & & & + \\
\hline & MEF18_I1 (serotype & & & + \\
\hline & 19F) & & & \\
\hline & MEF19_I1 & & & + \\
\hline & MEF26_I1 (serotype & & & + \\
\hline & $6 \mathrm{~A} / \mathrm{B})$ & & & \\
\hline & MEF27_I1 & \multirow{6}{*}{$\begin{array}{l}\text { Middle ear fluid of children with otitis media, Trofa Saúde Hospital Braga } \\
\text { Centro }\end{array}$} & & + \\
\hline & MEF28_I1 & & & + \\
\hline & $\begin{array}{l}\text { MEF29_I2 (serotype } \\
\text { 6A/B) }\end{array}$ & & & + \\
\hline & MEF33_I2 (serotype & & & + \\
\hline & $11 \mathrm{~A})$ & & & \\
\hline & MEF35_I1 & & & + \\
\hline & $\begin{array}{l}\text { C905005 (serotype } \\
\text { 1) }\end{array}$ & \multirow[b]{7}{*}{ Blood culture, Hospital de Braga } & & + \\
\hline & I891301 (serotype & & & + \\
\hline & $15 B / C)$ & & & \\
\hline & I895832 (serotype 1$)$ & & & + \\
\hline & I903728 (serotype & & & + \\
\hline & $19 \mathrm{~F})$ & & & \\
\hline & $\begin{array}{l}\text { U944982 (serotype } \\
\text { 4) }\end{array}$ & & & + \\
\hline \multirow[t]{3}{*}{ Streptococcus mitis } & I3124473 & Pus, Hospital de Braga & \multirow[t]{3}{*}{$37^{\circ} \mathrm{C}, 5 \% \mathrm{CO}_{2}$} & + \\
\hline & I310333 & Ocular, Hospital de Braga & & + \\
\hline & U374030 & Pus, Hospital de Braga & & + \\
\hline \multirow[t]{2}{*}{ Streptococcus agalactiae (Group B) } & I302171 & Placenta, Hospital de Braga & \multirow[t]{2}{*}{$37^{\circ} \mathrm{C}, 5 \% \mathrm{CO}_{2}$} & - \\
\hline & I303139 & Perianal abscess, Hospital de Braga & & - \\
\hline \multirow{2}{*}{$\begin{array}{l}\text { Streptococcus anginosus (Anginosus } \\
\text { group) }\end{array}$} & U365575 & Pus, Hospital de Braga & \multirow[t]{2}{*}{$37{ }^{\circ} \mathrm{C}, 5 \% \mathrm{CO}_{2}$} & - \\
\hline & I298561 & Blood culture, Hospital de Braga & & - \\
\hline \multirow[t]{2}{*}{ Streptococcus bovis (Group D) } & U344929 & Urine, Hospital de Braga & \multirow[t]{2}{*}{$37^{\circ} \mathrm{C}, 5 \% \mathrm{CO}_{2}$} & - \\
\hline & U238779 & Pleural washout, Hospital de Braga & & - \\
\hline $\begin{array}{l}\text { Streptococcus constellatus } \\
\quad \text { (Anginosus group) }\end{array}$ & I303868 & Periamydral abscess, Hospital de Braga & $37^{\circ} \mathrm{C}, 5 \% \mathrm{CO}_{2}$ & - \\
\hline \multirow[t]{2}{*}{ Streptococcus pyogenes (Group A) } & C124992 & Ocular, Hospital de Braga & \multirow[t]{2}{*}{$37{ }^{\circ} \mathrm{C}, 5 \% \mathrm{CO}_{2}$} & - \\
\hline & U164028 & Auricular, Hospital de Braga & & - \\
\hline Streptococcus salivarius & I299612 & Blood, Hospital de Braga & $37{ }^{\circ} \mathrm{C}, 5 \% \mathrm{CO}_{2}$ & - \\
\hline Streptococcus Group C & U269790 & Hemolysis, Hospital de Braga & $37{ }^{\circ} \mathrm{C}, 5 \% \mathrm{CO}_{2}$ & - \\
\hline \multirow[t]{2}{*}{ Streptococcus Group G } & U284971 & Hemolysis, Hospital de Braga & \multirow[t]{2}{*}{$37^{\circ} \mathrm{C}, 5 \% \mathrm{CO}_{2}$} & - \\
\hline & I196480 & Oropharynx, Hospital de Braga & & - \\
\hline Haemophilus influenzae & C894248 & Sputum, Hospital de Braga & $37^{\circ} \mathrm{C}, 5 \% \mathrm{CO}_{2}$ & - \\
\hline Moraxella catarrhalis & U225012 & Ocular, Hospital de Braga & $37{ }^{\circ} \mathrm{C}, 5 \% \mathrm{CO}_{2}$ & - \\
\hline Staphylococcus aureus & ATCC 6358 & Human lesion, American Type Culture Collection & $37^{\circ} \mathrm{C}$ & - \\
\hline Pseudomonas aeruginosa & PAO1 (DSM 22644) & $\begin{array}{l}\text { Infected wound, DSMZ - German Collection of Microorganisms and Cell } \\
\text { Cultures GmbH }\end{array}$ & $37^{\circ} \mathrm{C}$ & - \\
\hline Enterococcus faecalis & I809 & Urine, Hospital de Braga & $37^{\circ} \mathrm{C}$ & - \\
\hline
\end{tabular}

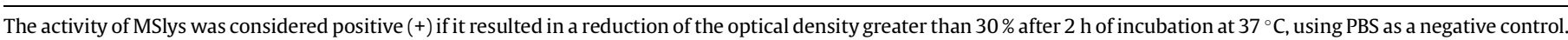


plasmid pET-28a(+) was purchased from Novagen (EMD Biosciences, Inc., Germany).

\subsection{In silico identification and characterization of MSlys}

The genome of Streptococcus phage MS1 (Accession No. KY629621.2) was analyzed to identify putative endolysins, and similarities to other endolysins searched using BLASTP. The search for functional domains was completed using both Pfam [16] and PROSITE [17], the molecular weight and isoelectric point predicted using ExPASy ProtParam [18], and protein alignment with other streptococcal endolysins was done with ClustalW 2.1 [19].

\subsection{Cloning}

DNA was extracted from phage lysates using the phenol: chloroform extraction method [20]. Open reading frames (ORFs) encoding MSlys and Pal were amplified by PCR (see primers, Table 2) using Phusion DNA Polymerase (ThermoScientific, MA, USA) following the manufacturer's instructions. PCR products were purified (D4005, ZYMO RESEARCH, CA, USA), double-digested with NdeI and HindIII-HF (NEB, MA, USA), and ligated to the pET-28a(+) vector using T4 DNA ligase. The insertion of the correct sequences into the plasmids was confirmed by Sanger sequencing. pET28a_MSlys and pET-28a_Pal were propagated and maintained in $E$. coli TOP10.

\subsection{Recombinant protein expression and purification}

E. coli BL21(DE3) cells with the recombinant plasmids were grown in $100 \mathrm{~mL}$ LB supplemented with $50 \mu \mathrm{g} / \mathrm{mL}$ of kanamycin (120 rpm, Orbital Shaker ES-20/60, BIOSAN, Latvia) to an optical density at $620 \mathrm{~nm}\left(\mathrm{OD}_{620}\right)$ of 0.5 . Recombinant protein expression was induced with $0.5 \mathrm{mM}$ IPTG, and cells incubated overnight $\left(16^{\circ} \mathrm{C}, 200 \mathrm{rpm}\right.$, Orbital Shaker MIR-S100, PHCbi, Japan). Cells were harvested $\left(9000 \times \mathrm{g}, 30 \mathrm{~min}, 4^{\circ} \mathrm{C}\right)$, resuspended in $5 \mathrm{~mL}$ of cold lysis buffer $\left(20 \mathrm{mM} \mathrm{NaH} \mathrm{PO}_{4}, 0.5 \mathrm{M} \mathrm{NaCl}, \mathrm{pH} \mathrm{7.4}\right)$, and disrupted through 3 cycles of freeze-thawing $\left(-80^{\circ} \mathrm{C}\right.$ to $\left.30^{\circ} \mathrm{C}\right)$. This was followed by 10 cycles of sonication on ice (30-sec pulse, 30-sec pause, $30 \%$ amplitude, Cole-Parmer Ultrasonic processor, CP-750, Illinois, USA). Insoluble cell debris was removed by centrifugation $\left(9000 \times \mathrm{g}, 20 \mathrm{~min}, 4^{\circ} \mathrm{C}\right)$. The supernatant was collected and filtered through a $0.22 \mu \mathrm{m}$ PES membrane. Purification was performed through $0.5 \mathrm{~mL} \mathrm{Ni}^{2+}$-NTA agarose (HisPur ${ }^{\mathrm{TM}} \mathrm{Ni}-\mathrm{NTA}$ Resin, Thermo Scientific) stacked in a gravity flow column using imidazole concentrations $(25-300 \mathrm{mM})$ [21]. Purified proteins were analyzed by SDS-PAGE, followed by BlueSafe staining (NZYTech, Lisbon, Portugal). Endotoxins of the first and second elutions were removed using ToxOut Rapid Endotoxin Removal Kit (BioVision Inc., Gentaur Molecular Products BVBS, Kampenhout, Belgium). The buffer was exchanged to PBS $(8 \mathrm{~g} / \mathrm{L} \mathrm{NaCl}, 0.2 \mathrm{~g} / \mathrm{L}, 1.44 \mathrm{~g} / \mathrm{L}$ $\mathrm{Na}_{2} \mathrm{HPO}_{4}, 0.24 \mathrm{~g} / \mathrm{L} \mathrm{K \textrm {K } _ { 2 }} \mathrm{PO}_{4}, \mathrm{pH}$ 7.4) using Amicon Ultra ${ }^{\mathrm{B}} 0.5 \mathrm{~mL}$ (Merck). The protein concentration was determined using the Pierce $^{\mathrm{TM}}$ BCA Protein Assay Kit (Thermo Scientific).

\subsection{Circular dichroism $(C D)$}

Secondary structures of MSlys and Pal were analyzed by circular dichroism (CD) spectroscopy in the far-UV region (190-260 nm), using a Jasco J-1500 CD spectrometer as performed previously [22]. Secondary structure estimation was made using CDSSTR [23] and CONTINLL [24] routine of the DICHROWEB [25], and the analysis complemented using PSIPRED [26].

\subsection{Lytic spectra}

The spectrum of MSlys was determined using different bacteria (Table 1). Bacteria were grown overnight, cells harvested [5000 $\times \mathrm{g}$, $5 \mathrm{~min}$, room temperature (RT)], and resuspended in PBS. MSlys ( $20 \mu \mathrm{L}$, final concentration of $2 \mu \mathrm{M})$ or PBS $(20 \mu \mathrm{L}$, negative control) and $180 \mu \mathrm{L}$ of the bacterial culture were added and incubated at $37{ }^{\circ} \mathrm{C}$ with or without $5 \% \mathrm{CO}_{2}$ (depending on the species tested). The endolysin was considered active if there was at least a $30 \%$ decrease in $\mathrm{OD}_{620}$ within the $2 \mathrm{~h}$ assay.

For serotyping of $S$. pneumoniae strains, a multiplex PCR using sets of primers that target different serotypes $(1,2,3,4,5,6 \mathrm{~A} / \mathrm{B}, 6 \mathrm{C} /$ D, 7A/F, 7C, $9 \mathrm{~V} / 9 \mathrm{~A}, 9 \mathrm{~N} / \mathrm{L}, 11 \mathrm{~A}, 12 \mathrm{~F} / 12 \mathrm{~A} / 12 \mathrm{~B} / 44 / 46,14,15 \mathrm{~B} / \mathrm{C}, 16 \mathrm{~F}$, $17 \mathrm{~F}, 18 \mathrm{~A} / \mathrm{B} / \mathrm{C}, 19 \mathrm{~A}, 19 \mathrm{~F}, 20,22 \mathrm{~F} / 22 \mathrm{~A}, 23 \mathrm{~F}, 23 \mathrm{~B}, 23 \mathrm{~A}$ and $33 \mathrm{~F} / 33 \mathrm{~A} /$ 37) as well as the capsular polysaccharide (cps) locus was performed (Table S1) [27,28]. Bacterial colonies were resuspended in $200 \mu \mathrm{L}$ of NZY bacterial cell lysis buffer (NZYTech, Lisbon, Portugal), followed by heating at $95{ }^{\circ} \mathrm{C}$ for $15 \mathrm{~min}$. The Xpert Taq DNA Polymerase (Grisp, Porto, Portugal) was used for the multiplex PCR reaction following the manufacturer's instructions.

\subsection{Effect of $\mathrm{pH}$, temperature, and choline on the activity of MSlys}

S. pneumoniae R6st cells grown overnight were diluted 1:100 in fresh $\mathrm{THB}_{\mathrm{ye}}$ and allowed to grow until the exponential phase. The thermostability of MSlys was assessed by heating the endolysin samples at several temperatures for $30 \mathrm{~min}$. These samples were after cooled on ice (20 min), cells harvested (5000 $\times$ g, $5 \mathrm{~min}, \mathrm{RT}$ ), and resuspended in PBS. The influence of $\mathrm{pH}$ on MSlys activity was tested on harvested cells resuspended in universal buffer $(150 \mathrm{mM}$

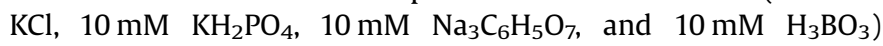
adjusted to a range of $\mathrm{pH}$ (5-10). For the evaluation of choline supplementation, harvested cells were resuspended in PBS containing different choline chloride (VWR) concentrations. The antibacterial effect of MSlys $(2 \mu \mathrm{M})$ was determined as described above $\left(37^{\circ} \mathrm{C}, 5 \% \mathrm{CO}_{2}\right)$, with the $\mathrm{OD}_{620}$ of MSlys-treated $S$. pneumoniae measured after $30 \mathrm{~min}, 1 \mathrm{~h}$, and $2 \mathrm{~h}$.

\subsection{Antibacterial activity against planktonic cells}

Antibacterial assays were performed as previously [22] with slight modifications. S. pneumoniae R6st cells, grown in $\mathrm{THB}_{\mathrm{ye}}$ overnight, were 1:100 diluted in fresh media and grown to the exponential phase. After, they were 100 -fold diluted in PBS. Each culture $(50 \mu \mathrm{L})$ was incubated at $37{ }^{\circ} \mathrm{C}$ with $5 \% \mathrm{CO}_{2}$, for $30 \mathrm{~min}, 1 \mathrm{~h}$ or $2 \mathrm{~h}$ with $50 \mu \mathrm{L}$ of endolysin at $2 \mu \mathrm{M}$ or $4 \mu \mathrm{M}$, or PBS (negative control). The effect was evaluated by 10 -fold diluting in saline $(0.9$

Table 2

List of primers used to clone the endolysins and their main characteristics. The restriction sites of the enzymes are underlined.

\begin{tabular}{|c|c|c|c|c|c|c|}
\hline Endolysin & Primer name & Primer sequence & Restriction enzyme & $\operatorname{Tm}\left({ }^{\circ} \mathrm{C}\right)$ & $\%$ GC & Product size (bp) \\
\hline \multirow[t]{2}{*}{ MSlys } & MS_FW & GGTTTCATATGGGAGTAAATATTGATGAAGGCGTTGC & NdeI & 59.2 & 41.4 & 906 \\
\hline & MS_RV & 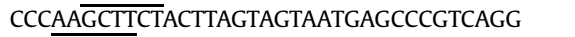 & HindIII & 57.7 & 48.1 & \\
\hline \multirow[t]{2}{*}{ Pal } & Pal_FW & GGTTTCATATGGGAGTCGATATTGAAAAAGGCGTTGC & NdeI & 61.1 & 44.8 & 909 \\
\hline & Pal_RV & 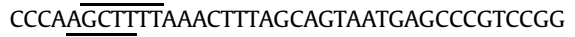 & HindIII & 61.7 & 46.7 & \\
\hline
\end{tabular}


$\%(\mathrm{w} / \mathrm{v}) \mathrm{NaCl})$ and plating on $\mathrm{TSA}_{\mathrm{sb}}$ to quantify the number of colony-forming units (CFU).

\subsection{Colony biofilm formation and endolysin treatment}

Overnight grown $S$. pneumoniae R6st cells were diluted to approximately $1 \times 10^{6} \mathrm{CFU} / \mathrm{mL}$, and biofilms formed for 24 , and $48 \mathrm{~h}$ on polycarbonate membranes $(0.1 \mu \mathrm{m}, 25 \mathrm{~mm}$, UV-sterilised on both sides, Whatman, GE Healthcare Life Sciences, PA, USA) as previously described [29]. Membranes were placed with the shiny side up onto TSA $\mathrm{sb}_{\mathrm{sb}}$ plates and inoculated with $50 \mu \mathrm{L}$ of culture, and incubated upright $\left(37^{\circ} \mathrm{C}, 5 \% \mathrm{CO}_{2}\right)$, being transferred to a fresh plate every $24 \mathrm{~h}$. For colony biofilm treatment with MSlys, membranes were transferred to 6-well plates, and $50 \mu \mathrm{L}$ of MSlys (final concentration of $4 \mu \mathrm{M}$ ) or PBS (negative control) were applied on the whole surface and incubated for $30 \mathrm{~min}, 1 \mathrm{~h}$ or $2 \mathrm{~h}$.

\subsubsection{Viable biofilm cell quantification}

After MSlys or PBS treatment, the membranes were transferred to PBS (1 mL), vortexed thoroughly, 10-fold diluted in saline, and plated on $\mathrm{TSA}_{\mathrm{sb}}$ to quantify the number of CFUs.

\subsubsection{Scanning electron microscopy (SEM)}

Biofilms formed on polycarbonate membranes treated with MSlys or PBS were fixed with $2.5 \%(\mathrm{v} / \mathrm{v})$ glutaraldehyde $\left(4^{\circ} \mathrm{C}, 1 \mathrm{~h}\right)$, and rinsed with PBS. Samples were dehydrated in ethanol series $(30,50,70,80,90 \%(v / v)$, and absolute), sputtered with gold, and analyzed by SEM (FEI Quanta 650 FEG, ThermoFisher Scientific).

\subsubsection{Confocal laser scanning microscopy (CLSM)}

Biofilms formed on polycarbonate membranes were fixed as above, rinsed with PBS, stained with 4',6-diamidino-2-phenylindole dihydrochloride (DAPI) according to the manufacturer's instructions (Invitrogen), and analyzed by CLSM (LSM780, Zeiss, Jena, Germany).

\subsection{Statistical analysis}

Mean and standard deviations (SD) were determined for at least three independent experiments. Statistical comparison was performed using Two-Way ANOVA and Tukey's multiple comparison statistical test, using GraphPad Prism 6. Differences were considered as statistically different if $\mathrm{P} \leq 0.05$ (95\% confidence interval).

\section{Results}

\subsection{MSlys characterization}

\subsubsection{In silico and circular dichroism (CD) analysis}

The genome of the lytic Streptococcus phage MS1 was checked for annotated endolysins. The gene ms1_61 annotated as a lysin was identified and named mslys. MSlys consists of 295 amino acids (AA) being a modular endolysin. Bioinformatics analysis shows that it comprises a catalytic domain with N-acetylmuramoyl-Lalanine amidase activity (Amidase_5; PF05382.13) and a cellbinding domain (or choline-binding domain) composed of 5 cellwall binding repeats (CW; PS51170) (Fig. S1). MSlys has a theoretical MW of $34.3 \mathrm{kDa}$ and a PI of 4.81. Although Pal is already well characterized, it was subjected to the same tools for analysis. Thus, Pal has 296 AAs encoding an N-terminal Amidase_5 domain and a choline-binding domain containing 6 CBRs (Fig. S1), having a MW of $34.5 \mathrm{kDa}$ and a PI of 4.95. BLASTp of MSlys showed $81 \%$ identity with Pal, and ClustalW showed a pairwise identity of 81.4\%, showing 241 identical and 55 different amino acids (Fig. S2).
MSlys and Pal were overexpressed in E. coli and purified, showing single bands on SDS-PAGE (Fig. S3) at the expected molecular weight (35.1 and $35.3 \mathrm{kDa}$, respectively, for MSlys and Pal, considering the N-terminal His-tag).

The CD spectrum of Pal showed two maximum peaks (at 220 and $240 \mathrm{~nm}$ ), one minimum peak (at $209 \mathrm{~nm}$ ) and one shoulder (at $200 \mathrm{~nm}$ ), while in the MSlys spectrum, two maximum peaks (at 220 and $240 \mathrm{~nm}$ ) and only one minimum peak (at $209 \mathrm{~nm}$ ) were observed (Fig. 1). Estimates of secondary structures by the deconvolution of the $\mathrm{CD}$ spectra indicate that both MSlys and Pal endolysins fold predominantly in $\beta$-sheets ( $43 \%$ as $\beta$-sheet, $4 \%$ as $\alpha$-helices, $21 \%$ as turns, and $32 \%$ unordered). This matches with the $\beta$-sheet prevalence predicted by PSIPRED (Fig. S4).

\subsubsection{Lytic spectra}

The lytic spectra of MSlys (Table 1) showed high specificity towards S. pneumoniae, killing all strains recovered from otitis media infections. These clinical isolates were collected from male and female children aged 1-5 years. Moreover, MSlys was effective against encapsulated pneumococcal strains with different serotypes, and also lysed the unencapsulated R6st (R6 streptomycin resistant) strain and the P046 strain (double lytA lytC mutant descended from the strain R6) (Table 1 and Fig. S5). Besides $S$. pneumoniae, MSlys also lysed Streptococcus mitis while all other streptococci and non-streptococci species were not affected by MSlys.

3.1.3. Effect of $\mathrm{pH}$, temperature, and choline on the activity of MSlys MSlys remained active after $30 \mathrm{~min}$ of incubation at $37^{\circ} \mathrm{C}$, slightly decreased activity after incubation at $40^{\circ} \mathrm{C}$, and became complete inactive after incubation at $50^{\circ} \mathrm{C}$ (Fig. 2a). Also, MSlys remained active between a pH of 6.0-9.0 (Fig. 2b). Supplementation of the lysis reaction with $2.5 \mathrm{mM}$ or less of choline did not significantly affect MSlys activity against S. pneumoniae after $2 \mathrm{~h}$ of treatment. However, $5 \mathrm{mM}$ and, more clearly, $10 \mathrm{mM}$ of choline reduced the action of MSlys against pneumococcal cells, with $20 \mathrm{mM}$ of choline completely inhibiting the activity of the endolysin.

\subsection{Antibacterial activity against planktonic cells}

The activity of MSlys and Pal against S. pneumoniae R6st cells was assessed at two different concentrations $(2 \mu \mathrm{M} \simeq 70 \mu \mathrm{g} / \mathrm{mL}$ and $4 \mu \mathrm{M} \simeq 140 \mu \mathrm{g} / \mathrm{mL}$ ) (Fig. 3 ).

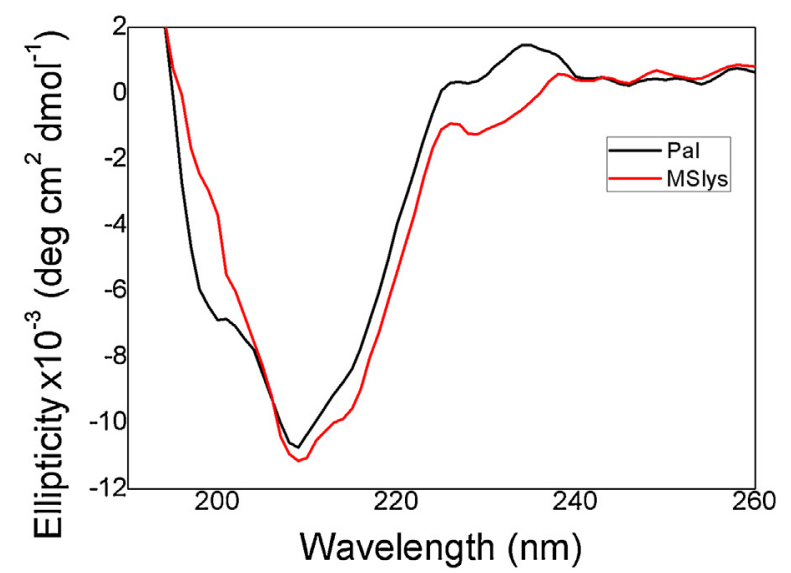

Fig. 1. Circular Dichroism spectra of pneumococcal endolysins. The spectrum of MSlys and Pal were analyzed in the far-UV $(190-260 \mathrm{~nm})$ using proteins dialyzed in PBS (pH 7.4). 

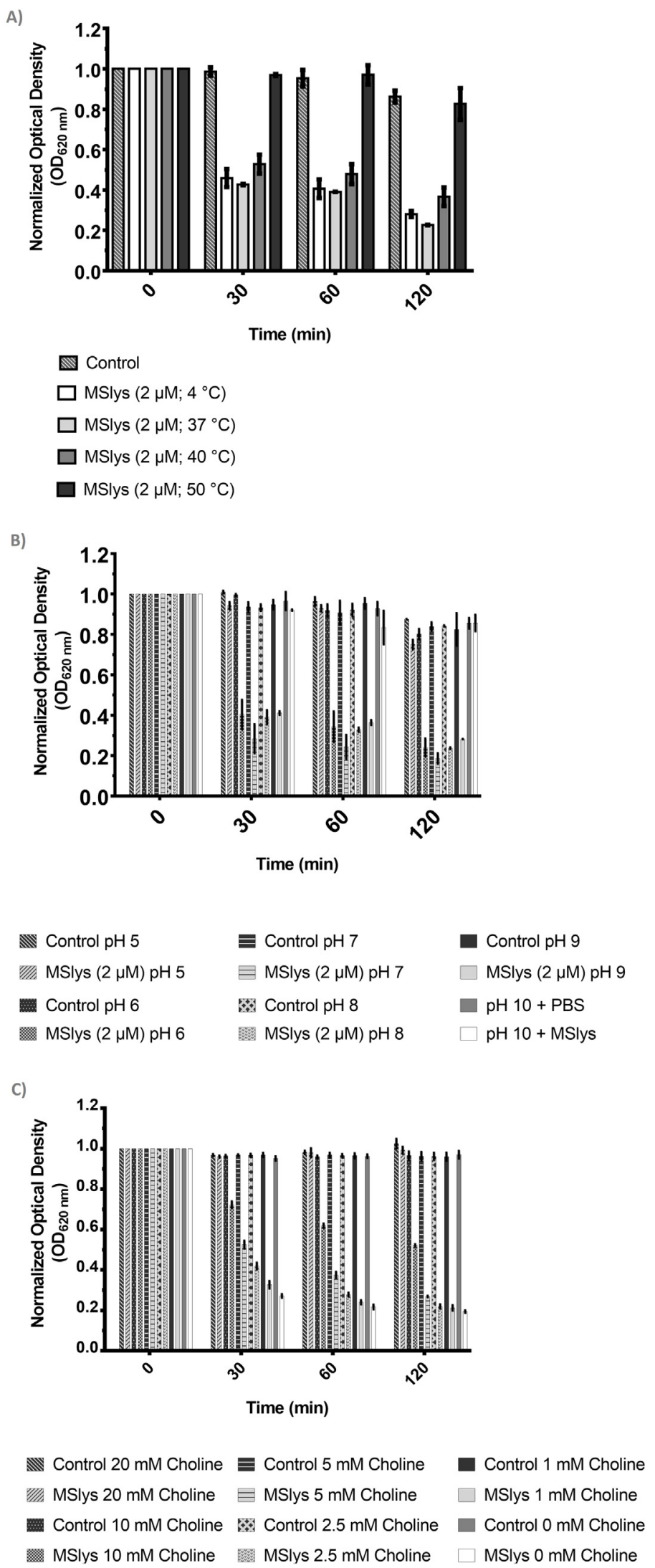

Fig. 2. Influence of the temperature, $\mathrm{pH}$ and choline on the activity of MSlys. a) The endolysin was incubated at different temperatures for $30 \mathrm{~min}$, cooled on ice for about 20 min and then used to treat $S$. pneumoniae cells suspended in PBS. b) The endolysin was used to treat $S$. pneumoniae cells suspended in universal buffer at
MSlys at $2 \mu \mathrm{M}$ reduced the number of cells significantly (2.5 $\left.\log _{10} \mathrm{CFU} / \mathrm{mL}\right)$ in $30 \mathrm{~min}(\mathrm{P} \leq 0.05)$ compared to the control. The decrease continued until $2 \mathrm{~h}\left(2.9 \log _{10} \mathrm{CFU} / \mathrm{mL}\right)$. No significant differences were obtained between 2 and $4 \mu \mathrm{M}$ of MSlys after $1 \mathrm{~h}$ post-treatment $(P>0.05)$. However, after $2 \mathrm{~h}$, MSlys at a final concentration of $4 \mu \mathrm{M}$ was significantly $(\mathrm{P} \leq 0.05)$ more pronounced, reducing the viable cells counts by $3.5 \log _{10} \mathrm{CFU} / \mathrm{mL}$.

Pal treatment at $2 \mu \mathrm{M}$ during $30 \mathrm{~min}$ or $1 \mathrm{~h}$ resulted in no significant differences compared with the control $(P>0.05)$, and led, after $2 \mathrm{~h}$, to a reduction of $0.88 \log _{10} \mathrm{CFU} / \mathrm{mL}$ compared with the controls. Pal at $4 \mu \mathrm{M}$ had enhanced antibacterial effect at all time points assessed $(\mathrm{P} \leq 0.05)$, resulting in an average reduction of $1.93 \log _{10} \mathrm{CFU} / \mathrm{mL}$ after the $2 \mathrm{~h}$ treatment. Nonetheless, MSlys showed significantly higher antibacterial activity compared to Pal $(\mathrm{P} \leq 0.05)$.

\subsection{Antibacterial activity of MSlys against biofilm cells}

Control biofilms reached $6.39 \pm 0.57 \log _{10} \mathrm{CFU} / \mathrm{mL}$ after $24 \mathrm{~h}$ and $6.28 \pm 0.17 \log _{10} \mathrm{CFU} / \mathrm{mL}$ after $48 \mathrm{~h}$ (Fig. 4). MSlys significantly reduced the number of 24 -h-old biofilms in all the time points tested $(\mathrm{P} \leq 0.05)$, reducing $0.84,0.92$, and $1.50 \log _{10} \mathrm{CFU} / \mathrm{mL}$ after $30 \mathrm{~min}, 1 \mathrm{~h}$, and $2 \mathrm{~h}$, respectively. MSlys also reduced 48 -h-old biofilms, achieving approximately the same reductions $(0.76,0.80$, and $1.80 \log _{10} \mathrm{CFU} / \mathrm{mL}$ after $30 \mathrm{~min}, 1 \mathrm{~h}$, and $2 \mathrm{~h}$, respectively). S. pneumoniae usually undergo autolysis to escape phagocytosis, but if autolysis had occurred, a CFU/mL decrease in the controls would be observed.

The effect of $2 \mathrm{~h}$ of MSlys treatment on 24-h and 48-h-old biofilms evaluated using SEM (Fig. 5) showed cells covering the polycarbonate membrane forming in some areas thick clusters (Fig. 5a and b). MSlys damaged the cells and increased the amount of cell debris in the surface (Fig. $5 c$ and d). The 48-h biofilms were denser with thicker cell clusters (Fig. 5e and f). Once more, MSlys was able to damage these 48 -h-old biofilms, increasing the amount of cell debris (Fig. $5 \mathrm{~g}$ and $\mathrm{h}$ ).

Taking into account the $z$-axis plot profile (mean $>20$ ), the average thickness of the 24-h-old biofilms was $45.33 \pm 1.15 \mu \mathrm{m}$, and of the 48 -h-old was $132.00 \pm 28.62 \mu \mathrm{m}$. CLSM analysis showed that MSlys caused changes in the biofilm thickness (Fig. 6), indicating that this endolysin lysed pneumococcal cells within the biofilm structures. The average thickness of 24-h-old biofilms after MSlys treatment was $12.67 \pm 1.15 \mu \mathrm{m}$. The biofilm thickness reduction was not as visible in the 24 -h-old biofilms treated with MSlys (see Fig. 6a and b), compared to the 48-h-old treated biofilms that showed an average thickness of $87.00 \pm 4.24 \mu \mathrm{m}$ (see Fig. 6c and d).

\section{Discussion}

The virulent MS1 phage is related to phage Dp-1, presenting an average nucleotide identity of $73.3 \%$ on $62.3 \%$ of the aligned nucleotides [8]. In our study, we recombinantly expressed the endolysin of phage MS1 (MSlys) and Pal endolysin from Dp-1. MSlys and Pal endolysins are similar, being both modular proteins with a catalytic module belonging to the Amidase_5 family and a choline-binding module. The catalytic domain ( $\mathrm{N}$-acetylmuramoyl-t-alanine amidase) is responsible for the cell wall degradation through hydrolysis of the amide bond between the muramic acid and the L-alanine. The binding domain is responsible for the

different $\mathrm{pH}$. c) The endolysin was used to treat $S$. pneumoniae cells suspended in PBS containing different concentrations of choline. The reduction in the optical density reduction of $S$. pneumoniae R6st cells after treatment with MSlys ( $2 \mu \mathrm{M})$ for $2 \mathrm{~h}$ at $37^{\circ} \mathrm{C}$ was monitored. Normalized data are shown as mean \pm SD. 
A)

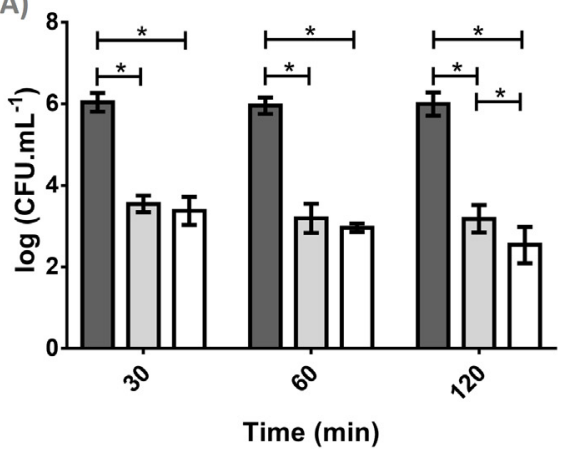

$\square$ Control $\square$ MSlys (2 $\mu \mathrm{M})$

MSlys $(4 \mu \mathrm{M})$

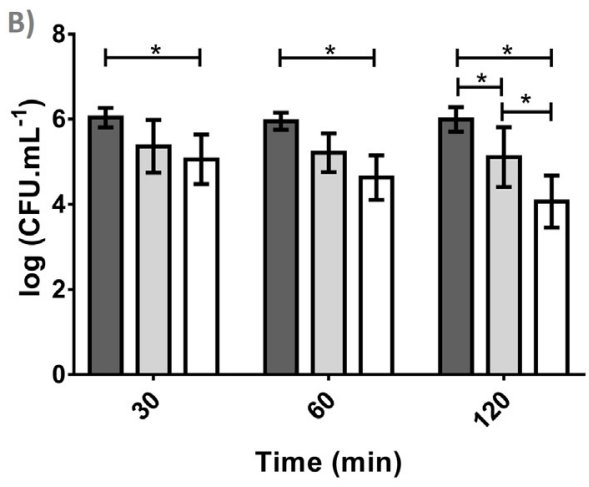

Control $\square$ Pal (2 $\mu \mathrm{M})$

Pal $(4 \mu \mathrm{M})$

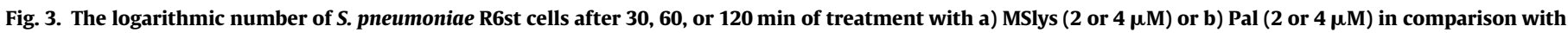
control (PBS). Data are shown as mean \pm SD. Differences were considered statistically significant if $\mathrm{P} \leq 0.05\left({ }^{*}\right)$.

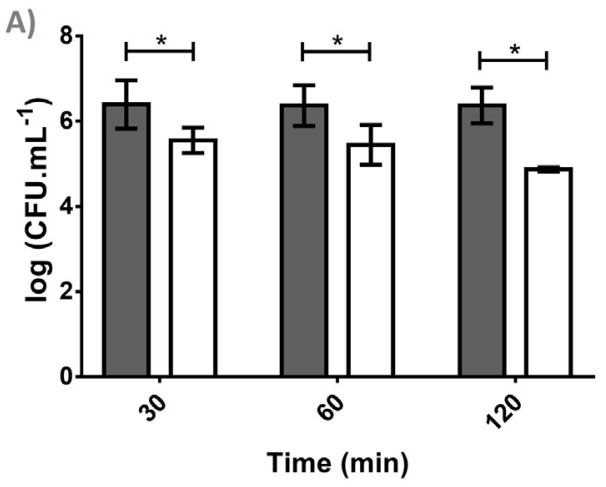

Control

MSlys $(4 \mu \mathrm{M})$

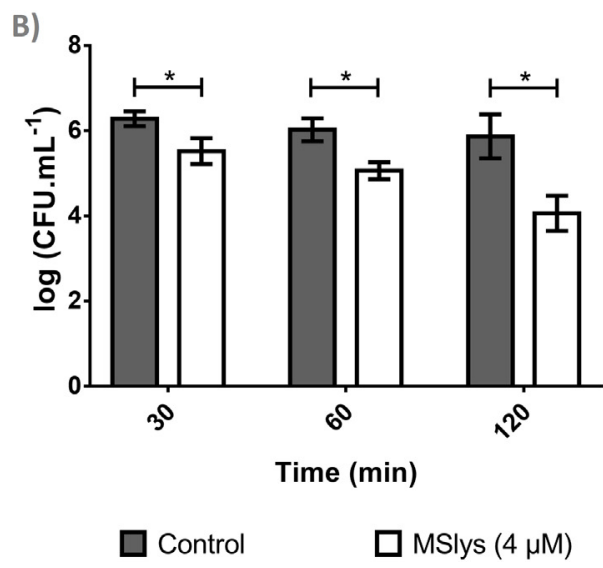

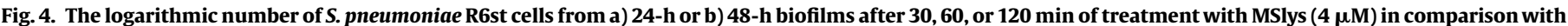
control (PBS). Data are shown as mean \pm SD. Differences were considered statistically significant if $\mathrm{P} \leq 0.05\left({ }^{*}\right)$.

attachment to choline residues present in the pneumococcal envelope [30]. In silico analysis showed that the protein sequences differ in the number of cell wall-binding repeats (CW), with MSlys having $5 \mathrm{CW}$ while Pal presents 6 . However, the number of $\mathrm{CW}$ obtained differs using different software. For instance, Pal shows 6 $[15,30]$, and $7 \mathrm{CW}$ in published literature [31]. Some authors hypothesized that the affinity for choline was related to the number of CW. Still, other studies have refuted this assumption, showing that the increase in the number of CW seems to be associated with a stronger choline-binding, but this still needs to be validated [15].

The antibacterial effect of MSlys was specific for S. pneumoniae, including strains isolated from the middle ear fluid of children with otitis media. It has been demonstrated that most clinical pneumococcal strains express capsule [32]. However, nonencapsulated $S$. pneumoniae (NESp) have been isolated from patients with otitis media $[33,34]$ and are reported as a potential causative agent of chronic or recurrent otitis media [35]. Although only a few of the middle ear fluid isolates belonging to serotypes $6 \mathrm{~A} / \mathrm{B}, 11 \mathrm{~A}$ and $19 \mathrm{~F}$ were identified, MSlys was effective against these capsule expressing strains, as well as against five other encapsulated $S$. pneumoniae strains (serotypes 1, 4, 15B/C, 19 F) isolated from sputum and blood. Some serotypes identified are covered by the 13 -valent pneumococcal conjugate vaccine $(1,4,6 \mathrm{~A}$, $6 \mathrm{~B}, 19 \mathrm{~F})$, which is included in the national immunization program in Portugal since 2015 [36]. MSlys also killed an unencapsulated strain lacking the autolysin gene, showing that its activity is independent of the host autolysin. Besides S. pneumonie, MSlys lysed $S$. mitis but did not affect other Streptococcus species tested and non-streptococcal species. This specificity is in agreement with previous reports for choline-binding proteins, such as Pal, Cpl-1, and PL3 [31]. Due to the presence of the choline-binding domain, it was already expected that MSlys would be specific for bacteria containing choline in their cell walls. For instance, Pal and Cpl-1 kill at a lower rate Streptococcus oralis and S. mitis, which incorporate choline in their cell walls [9,10], and the chimeric enzyme PL3, derived from Pal, killed S. oralis, Streptococcus pseudopneumoniae, and S. mitis type [37]. The specific binding of MSlys to pneumococcal strains and a few related species is advantageous, since this provides a targeted killing and prevents collateral effects on commensal bacteria and dysbiosis [21]. In contrast, Cpl-7 and Cpl-7S have a different binding domain, composed of 3 identical CW_7 tandem repeats, that confer the ability to degrade pneumococcal cell walls containing either choline or ethanolamine. These endolysins lyse a broader range of bacteria, including S. pneumoniae and other Gram-positive pathogens $[38,39]$.

In this work, Pal structure analysis using $C D$ agreed with a previous report [37]. The authors theorized that the CD signature of Streptococcus phage endolysins Pal and PL3, with two maximum peaks (at 220-240 nm) and the negative band (peak in PL3 and shoulder in Pal at $200 \mathrm{~nm}$ ) corresponded to a fingerprint of the 
Amidase_5 domain. MSlys, which also encodes an Amidase_5 domain, does not present a negative peak or shoulder (at $200 \mathrm{~nm}$ ). Both MSlys and Pal secondary structures are mostly composed of $\beta$ sheets. In a previous study, deconvolution of the CD spectrum showed that the secondary structure content of Pal corresponded to $45 \% \beta$-strands, $7 \% \alpha$-helices, $21 \%$ turns, and $24 \%$ unordered [ 40 ], being close to the values that were obtained herein. The same authors suggested an influence of choline in the tertiary and quaternary structures. Considering the similarity between Pal and MSlys, the same fact can be hypothesized for MSlys. The rich $\beta$ - sheet content of Pal and MSlys are different from other pneumococcal endolysins characterized by similar methods, such as Cpl-7 and derived engineered enzymes (Cpl-7S, Cpl-711), which are predicted to have rich $\alpha$-helix content [38,39,41], but less different from Cpl-1 (19\% $\alpha$-helices, $32 \% \beta$-sheet, $28 \% \beta$-turn, $21 \%$ random coil) [42].

MSlys was stable after exposure until $37^{\circ} \mathrm{C}$, with a slight stability decrease starting at $40^{\circ} \mathrm{C}$. MSlys was stable between a $\mathrm{pH}$ of 6.0-9.0, just like Pal [31]. These biochemical properties are fundamental, allowing MSlys to kill in conditions found in the
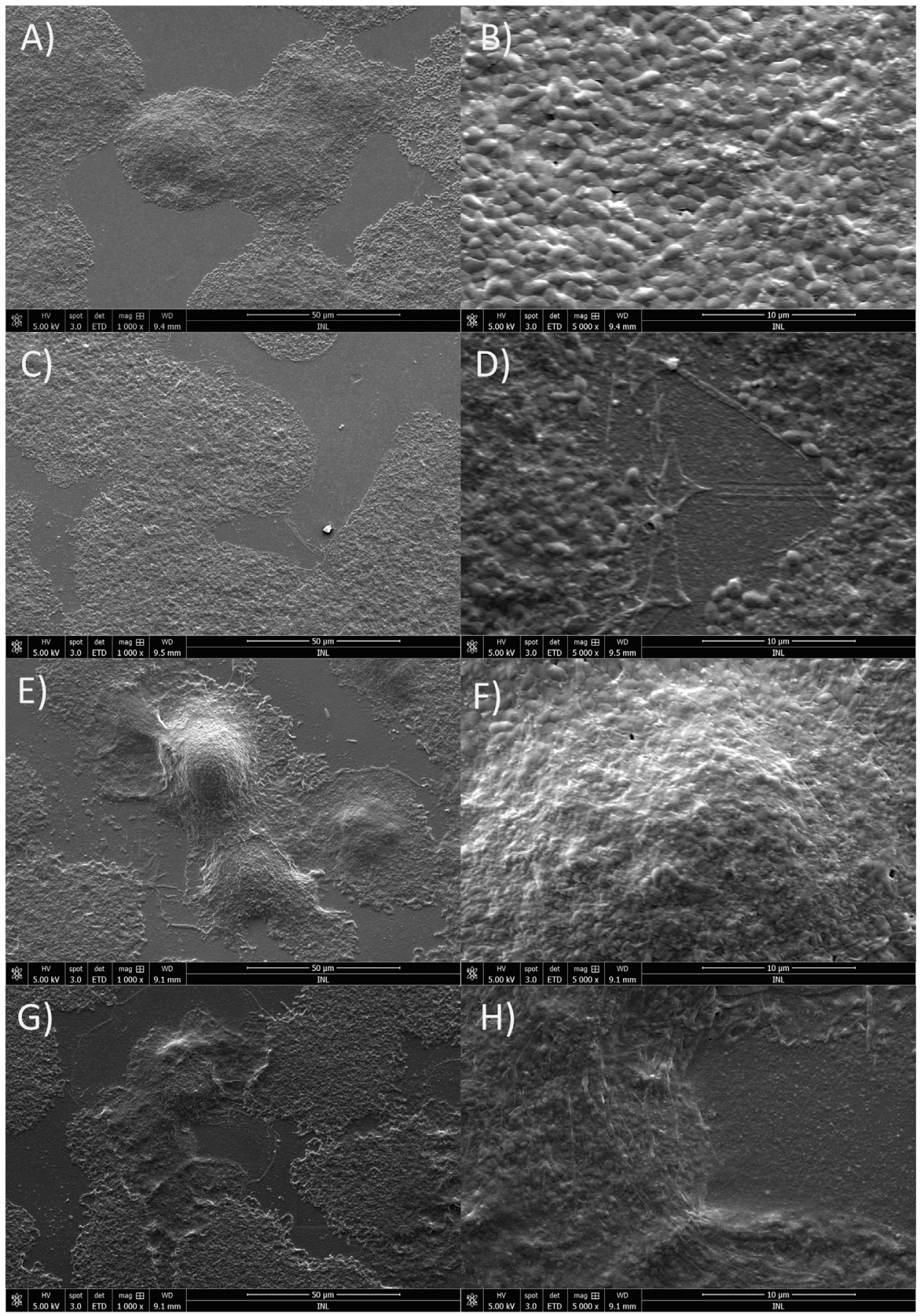

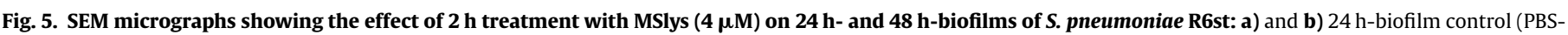
treated); c) and d) 24-h biofilm treated with MSlys; e) and f) 48 h-biofilm control (PBS-treated); g) and h) 48 h-biofilm treated with MSlys. 


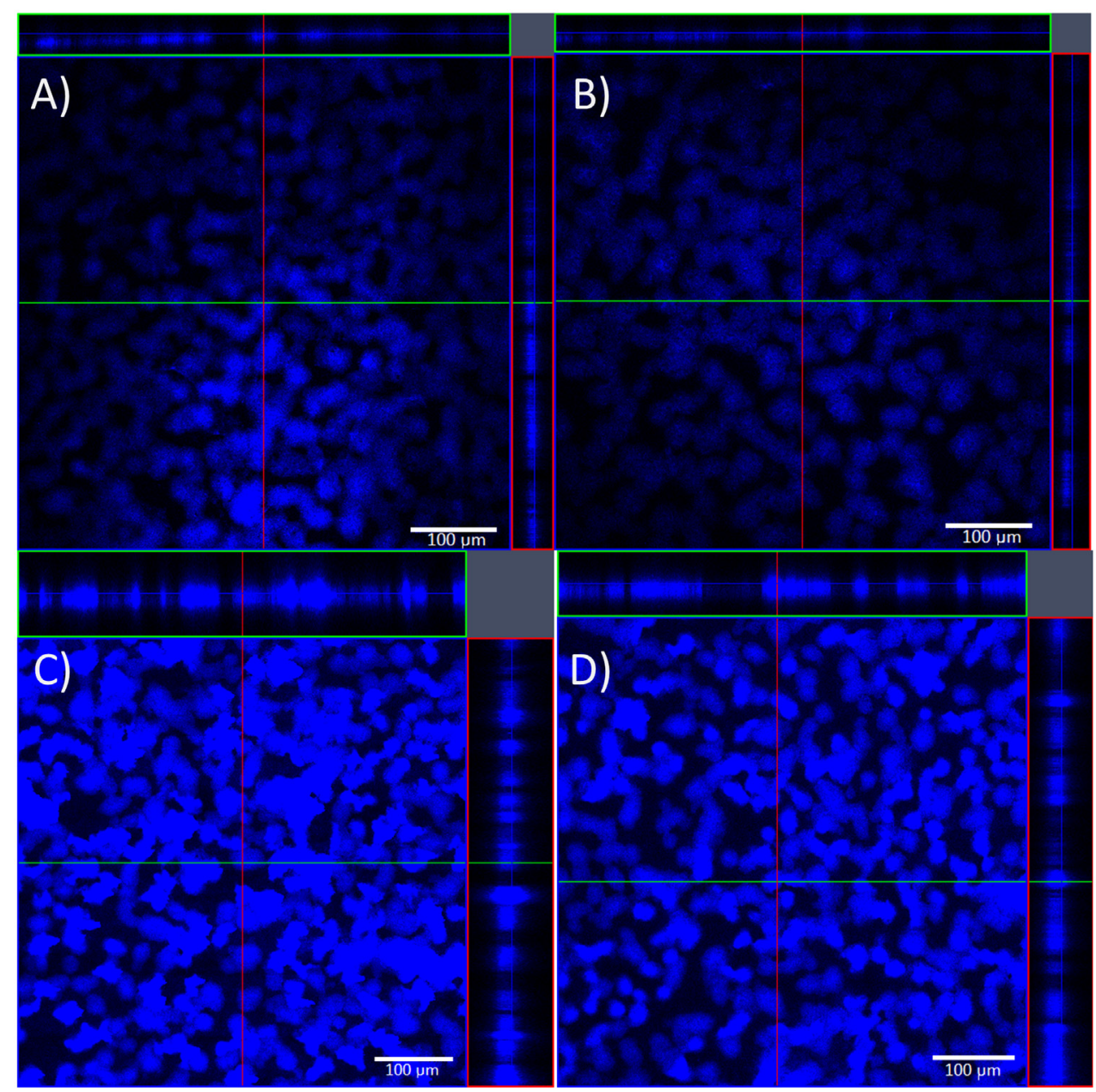

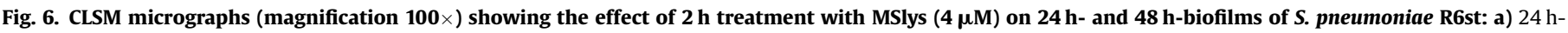
biofilm control (PBS-treated); b) 24-h biofilm treated with MSlys; c) 48 h-biofilm control (PBS-treated); d) 48 h-biofilm treated with MSlys.

middle ear during infection. The mean ear temperature is $36.4 \pm 0.61^{\circ} \mathrm{C}$, increasing by $1.0-1.5^{\circ} \mathrm{C}$ when feverish [43], while the mean $\mathrm{pH}$ of the middle ear fluid of children with otitis media varies between $8.55,8.33$, and 7.92 in the case of mucous, serousmucous, and serous secretions [44]. Being a choline-binding protein, MSlys might be inhibited by the presence of choline (in the tens of millimolar range) or choline analogs, such as esters of bicyclic amines, that compete with the choline present in the pneumococcal cell wall [45]. Indeed, the activity of MSlys was entirely inhibited by supplementation of the lysis reaction with $20 \mathrm{mM}$ of choline.

Despite the similarity between MSlys and Pal, in this study, the activity of MSlys against S. pneumoniae R6st planktonic cells was significantly better, after $2 \mathrm{~h}$, compared to Pal using 2 and $4 \mu \mathrm{M}$ endolysin concentrations. MSlys killed faster, decreasing the number of cells considerably after $30 \mathrm{~min}$, and continued to decline until the end of the experiment. Overall, MSlys reduced the number of viable cells by 3.5 logarithmic units, whereas a maximum decrease of $1.93 \log _{10} \mathrm{CFU} / \mathrm{mL}$ was obtained using 4 $\mu \mathrm{M}$ of Pal after $2 \mathrm{~h}$. The anti-pneumococcal effect was demonstrated to be concentration-dependent, with a lower concentration of MSlys needed compared to Pal.

S. pneumoniae biofilms are a significant concern, having been identified in the middle ear mucosa specimens of children diagnosed with chronic otitis media with effusion [46] and in adenoid samples from children with recurrent acute otitis media [47]. MSlys was able to kill cells from 24 and 48-h-old biofilms, reducing the viable cell counts after $2 \mathrm{~h}$ by approximately 1.5 (96.84\%) and $1.8 \log _{10} \mathrm{CFU} / \mathrm{mL}$ (98.42\%), respectively. Pal was previously reported to reduce nearly $90 \%$ of biofilm-cells after $4 \mathrm{~h}$ of treatment [31]. However, the authors decided to use strain P046 (a double lytA lytC mutant of the R6 strain), which is unable to autolyze, for their biofilm assays ( 96 -well plates, $14-16 \mathrm{~h}, 34^{\circ} \mathrm{C}, 5 \%$ $\mathrm{CO}_{2}$ ). Although the method of biofilm formation used was different, increased activity of MSlys against 24-h biofilms and already after $2 \mathrm{~h}$ was observed in this study compared to reported for Pal. In a subsequent investigation, treatment of $S$. pneumoniae P046 24-h-old biofilms with the engineered endolysin Cpl-711 at $1 \mu \mathrm{g} / \mathrm{mL}$ for $2 \mathrm{~h}$ killed about 4 logs of the bacterial population. At the same time, Cpl-1 and Cpl-7 reduced biofilms cells by approximately 1.5 logarithmic units [41]. The activity of the engineered endolysin is undoubtedly much higher than MSlys. However, the values obtained with the natural phage-encoded enzymes Cpl-1 and Cpl-7 are comparable to the ones observed for MSlys. The synergy between the enzymes Cpl-711 and PL3 against S. pneumoniae biofilms formed at $34^{\circ} \mathrm{C}$ for $14-16 \mathrm{~h}$ was also reported [48]. Treatment with the combination of $0.5 \times$ MIC of the endolysins for $1 \mathrm{~h}$ reduced cells in biofilms by more than $4.0 \log _{10}$ $\mathrm{CFU} / \mathrm{mL}$, representing an increase of 3.6 logs compared to the sum of activities of the individual Cpl-711 or PL3 treatments. So, 
combining MSlys with another endolysin can be another strategy to enhance their antibacterial activity against pneumococcal biofilms. The potential of MSlys against pneumococcal biofilms was corroborated by SEM, where damaged cells and an increase of cell debris due to the endolysin were observed, and also by CLSM, where a significant difference in biofilm thickness was observed between treated and control samples. This result seems to be similar to the one obtained by previous authors [31]. These authors showed that two S. pneumoniae endolysins disintegrated biofilm, analysed by crystal violet (CV) staining of the total biofilm biomass, resulting in a reduction of around $70 \%$ (Cpl-7), and $55 \%$ (Cpl-1). Due to the similarity between MSlys and Pal, one would expect that their action towards biofilms would be comparable. However, this was not observed since Pal did not damage the biofilm structures as analyzed both by CLSM and CV staining [31].

During the last few years, protein engineering has improved properties of $S$. pneumoniae endolysins, i.e., has amplified their antimicrobial activity, increased their plasma half-time, and their capacity to pass through the negatively charged bacterial envelope. These improvements have been accomplished by the inclusion of new residues (Cpl-1 dimer) [49], inversion of the charge of the cell wall binding domain (Cpl-7S) [39], and domain swapping/fusion (Cpl-711, PL3) [37,41]. The natural MSlys is not as efficient as engineered endolysins; nevertheless, it presents excellent features against S. pneumoniae.

In summary, we characterized a novel natural pneumococcal endolysin, which is structurally very similar to Pal. MSlys was shown to be very effective against $S$. pneumoniae planktonic and biofilm cells. Furthermore, we showed that its activity is specific for S. pneumoniae and S. mitis, lysing pneumococcal strains isolated from otitis media infections. Also, MSlys was shown to be active in conditions commonly found in the middle ear during disease.

\section{Funding}

MDS acknowledges the Portuguese Foundation for Science and Technology (FCT) grant (SFRH/BD/128825/2017). This study was supported by the Portuguese Foundation for Science and Technology (FCT) under the scope of the strategic funding of UID/BIO/04469/2019unit and BioTecNorte operation (NORTE-010145-FEDER-000004) funded by the European Regional Development Fund under the scope of Norte2020 - Programa Operacional Regional do Norte. This project also received funding from the European Union's Horizon 2020 research and innovation programme under grant agreement No 713640. This study was also supported by the grant PTDC/CVT-CVT/29628/2017 [POCI-010145-FEDER-029628].

\section{CRediT authorship contribution statement}

Maria Daniela Silva: Conceptualization, Methodology, Investigation, Writing - original draft. Hugo Oliveira: Investigation. Alberta Faustino: Investigation. Sanna Sillankorva: Conceptualization, Methodology, Writing - review \& editing, Funding acquisition, Resources, Supervision.

\section{Declaration of Competing Interest}

The authors report no declarations of interest.

\section{Acknowledgments}

The authors acknowledge the Department of Otolaryngology of Hospital de Braga and Trofa Saúde Hospital Braga Centro and Braga Sul for collecting the middle ear fluid samples of children with otitis media. The authors acknowledge Dr. Pedro García from both
Centro de Investigaciones Biológicas (CSIC) and CIBER de Enfermedades Respiratorias, Madrid, Spain, for providing the double lytA lytC R6 mutant S. pneumoniae P046 strain.

\section{Appendix A. Supplementary data}

Supplementary material related to this article can be found, in the online version, at doi:https://doi.org/10.1016/j.btre.2020. e00547.

\section{References}

[1] J.N. Weiser, D.M. Ferreira, J.C. Paton, Streptococcus pneumoniae: transmission, colonization and invasion, Nat. Rev. Microbiol. 16 (2018) 355-367, doi:http:// dx.doi.org/10.1038/s41579-018-0001-8.

[2] A.L. Andrade, C.M. Toscano, R. Minamisava, P.S. Costa, J.G. Andrade, Pneumococcal disease manifestation in children before and after vaccination: what's new? Vaccine 29 (2011) C2-C14, doi:http://dx.doi.org/ 10.1016/j.vaccine.2011.06.096.

[3] World Health Organization WHO, Pneumococcal conjugate vaccine for childhood immunization - WHO position paper, Bull. Epidemiol. Inf. Receiv. 82 (2007) 93-104. http://www.ncbi.nlm.nih.gov/pubmed/17380597.

[4] R.M. Donlan, Biofilms: Microbial life on surfaces, Emerg. Infect. Dis. 8 (2002) 881-890, doi:http://dx.doi.org/10.3201/eid0809.020063.

[5] J.W. Costerton, Bacterial biofilms: a common cause of persistent infections, Science 284 (1999) 1318-1322, doi:http://dx.doi.org/10.1126/ science.284.5418.1318.

[6] E. Tacconelli, N. Magrini, G. Kahlmeter, N. Singh, Global Priority List of Antibiotic-Resistant Bacteria to Guide Research, Discovery, and Development of New Antibiotics, World Heal. Organ, 2017, pp. 1-7.

[7] R. López, E. García, Recent trends on the molecular biology of pneumococcal capsules, lytic enzymes, and bacteriophage, FEMS Microbiol. Rev. 28 (2004) 553-580, doi:http://dx.doi.org/10.1016/j.femsre.2004.05.002.

[8] W. Kot, M. Sabri, H. Gingras, M. Ouellette, D.M. Tremblay, S. Moineau, Complete genome sequence of Streptococcus pneumoniae virulent Phage MS1, Genome Announc. 5 (2017) 4-5, doi:http://dx.doi.org/10.1128/genomeA.00333-17.

[9] J.M. Loeffler, Rapid killing of Streptococcus pneumoniae with a bacteriophage cell wall hydrolase, Science 294 (2001) 2170-2172, doi:http://dx.doi.org/ $10.1126 /$ science.1066869.

[10] J.M. Loeffler, V.A. Fischetti, Synergistic lethal effect of a combination of phage lytic enzymes with different activities on penicillin-sensitive and -resistant Streptococcus pneumoniae strains, Antimicrob. Agents Chemother. 47 (2003) 375-377, doi:http://dx.doi.org/10.1128/AAC.47.1.375-377.2003.

[11] S. Djurkovic, J.M. Loeffler, V.A. Fischetti, Synergistic killing of Streptococcus pneumoniae with the bacteriophage lytic enzyme Cpl-1 and penicillin or gentamicin depends on the level of penicillin resistance, Antimicrob. Agents Chemother. 49 (2005) 1225-1228, doi:http://dx.doi.org/10.1128/ AAC.49.3.1225-1228.2005.

[12] J.M. Loeffler, S. Djurkovic, V.A. Fischetti, Phage lytic enzyme Cpl-1 as a novel antimicrobial for pneumococcal bacteremia, Infect. Immun. 71 (2003) 61996204, doi:http://dx.doi.org/10.1128/IAI.71.11.6199-6204.2003.

[13] J.M. Entenza, J.M. Loeffler, D. Grandgirard, V.A. Fischetti, P. Moreillon, Therapeutic effects of bacteriophage Cpl-1 lysin against Streptococcus pneumoniae endocarditis in rats, Antimicrob. Agents Chemother. 49 (2005) 4789-4792, doi:http://dx.doi.org/10.1128/AAC.49.11.4789-4792.2005.

[14] J.A. McCullers, Å. Karlström, A.R. Iverson, J.M. Loeffler, V.A. Fischetti, Novel strategy to prevent otitis media caused by colonizing Streptococcus pneumoniae, PLoS Pathog. 3 (2007) e28, doi:http://dx.doi.org/10.1371/journal. ppat.0030028.

[15] B. Maestro, J. Sanz, Choline binding proteins from Streptococcus pneumoniae: a dual role as enzybiotics and targets for the design of new antimicrobials, Antibiotics 5 (2016) 21, doi:http://dx.doi.org/10.3390/antibiotics5020021.

[16] R.D. Finn, P. Coggill, R.Y. Eberhardt, S.R. Eddy, J. Mistry, A.L. Mitchell, S.C. Potter, M. Punta, M. Qureshi, A. Sangrador-Vegas, G.A. Salazar, J. Tate, A. Bateman, The Pfam protein families database: towards a more sustainable future, Nucleic Acids Res. 44 (2016) D279-D285, doi:http://dx.doi.org/10.1093/nar/gkv1344.

[17] C.J.A. Sigrist, E. De Castro, L. Cerutti, B.A. Cuche, N. Hulo, A. Bridge, L Bougueleret, I. Xenarios, New and continuing developments at PROSITE, Nucleic Acids Res. (2013), doi:http://dx.doi.org/10.1093/nar/gks1067.

[18] E. Gasteiger, C. Hoogland, A. Gattiker, S. Duvaud, M.R. Wilkins, R.D. Appel, A. Bairoch, Protein identification and analysis tools on the ExPASy server, Proteomics Protoc. Handb., Humana Press, Totowa, NJ, 2005, pp. 571-607, doi: http://dx.doi.org/10.1385/1-59259-890-0:571.

[19] M.A. Larkin, G. Blackshields, N.P. Brown, R. Chenna, P.A. Mcgettigan, H McWilliam, F. Valentin, I.M. Wallace, A. Wilm, R. Lopez, J.D. Thompson, T.J. Gibson, D.G. Higgins, Clustal W and Clustal X version 2.0, Bioinformatics (2007), doi:http://dx.doi.org/10.1093/bioinformatics/btm404.

[20] J.F. Sambrook, D.W. Russell, Molecular Cloning: A Laboratory Manual, third edition, Cold Spring Harbor Laboratory Press, 2001.

[21] M. Harhala, D. Nelson, P. Miernikiewicz, R. Heselpoth, B. Brzezicka, J Majewska, S. Linden, X. Shang, A. Szymczak, D. Lecion, K. Marek-Bukowiec, M. Kłak, B. Wojciechowicz, K. Lahutta, A. Konieczny, K. Dąbrowska, Safety 
studies of pneumococcal endolysins Cpl-1 and Pal, Viruses 10 (2018) 638, doi: http://dx.doi.org/10.3390/v10110638.

[22] H. Oliveira, D. Vilas Boas, S. Mesnage, L.D. Kluskens, R. Lavigne, S. Sillankorva, F. Secundo, J. Azeredo, Structural and enzymatic characterization of ABgp46, a novel phage endolysin with broad anti-Gram-negative bacterial activity, Front. Microbiol. 7 (2016) 1-9, doi:http://dx.doi.org/10.3389/fmicb.2016.00208.

[23] L.A. Compton, W.C. Johnson, Analysis of protein circular dichroism spectra for secondary structure using a simple matrix multiplication, Anal. Biochem. 155 (1986) 155-167, doi:http://dx.doi.org/10.1016/0003-2697(86)90241-1.

[24] I.H.M. Van Stokkum, H.J.W. Spoelder, M. Bloemendal, R. Van Grondelle, F.C.A. Groen, Estimation of protein secondary structure and error analysis from circular dichroism spectra, Anal. Biochem. (1990), doi:http://dx.doi.org/ 10.1016/0003-2697(90)90396-Q.

[25] L. Whitmore, B.A. Wallace, DICHROWEB, an online server for protein secondary structure analyses from circular dichroism spectroscopic data, Nucleic Acids Res. (2004), doi:http://dx.doi.org/10.1093/nar/gkh371.

[26] L.J. McGuffin, K. Bryson, D.T. Jones, The PSIPRED protein structure prediction server, Bioinformatics (2000), doi:http://dx.doi.org/10.1093/bioinformatics/ 16.4.404.

[27] Centers for Disease Control and Prevention, Conventional PCR Serotype Deduction Protocols, (n.d.). https://www.cdc.gov/streplab/pneumococcus/ resources.html.

[28] R. Pai, R.E. Gertz, B. Beall, Sequential multiplex PCR approach for determining capsular serotypes of Streptococcus pneumoniaeisolates, J. Clin. Microbiol. 44 (2006) 124-131, doi:http://dx.doi.org/10.1128/JCM.44.1.124-131.2006.

[29] J.H. Merritt, D.E. Kadouri, G.A. O’Toole, Growing and analyzing static biofilms, Curr. Protoc. Microbiol., (2005), doi:http://dx.doi.org/10.1002/ 9780471729259.mc01b01s00.

[30] M.M. Sheehan, J.L. García, R. López, P. García, The lytic enzyme of the pneumococcal phage Dp-1: a chimeric lysin of intergeneric origin, Mol. Microbiol. 25 (1997) 717-725, doi:http://dx.doi.org/10.1046/j.13652958.1997.5101880.x.

[31] M. Domenech, E. Garciá, M. Moscoso, In vitro destruction of Streptococcus pneumoniae biofilms with bacterial and phage peptidoglycan hydrolases, Antimicrob. Agents Chemother. 55 (2011) 4144-4148, doi:http://dx.doi.org/ 10.1128/AAC.00492-11.

[32] P. Kurola, L. Erkkilä, T. Kaijalainen, A.A. Palmu, W.P. Hausdorff, J. Poolman, J. Jokinen, T.M. Kilpi, M. Leinonen, A. Saukkoriipi, Presence of capsular locus genes in immunochemically identified encapsulated and unencapsulated Streptococcus pneumoniae sputum isolates obtained from elderly patients with acute lower respiratory tract infection, J. Med. Microbiol. 59 (2010) 1140-1145, doi:http://dx.doi.org/10.1099/jmm.0.016956-0.

[33] Q. Xu, R. Kaur, J.R. Casey, V. Sabharwal, S. Pelton, M.E. Pichichero, Nontypeable Streptococcus pneumoniae as an otopathogen, Diagn. Microbiol. Infect. Dis. 69 (2011) 200-204, doi:http://dx.doi.org/10.1016/j.diagmicrobio.2010.09.019.

[34] L.E. Keller, D.A. Robinson, L.S. McDaniel, Nonencapsulated Streptococcus pneumoniae: emergence and pathogenesis, MBio 7 (2016)1-12, doi:http://dx. doi.org/10.1128/mBio.01792-15.

[35] K.A. Murrah, B. Pang, S. Richardson, A. Perez, J. Reimche, L. King, J. Wren, W.E. Swords, Nonencapsulated Streptococcus pneumoniae causes otitis media during single-species infection and during polymicrobial infection with nontypeable Haemophilus influenzae, Pathog. Dis. 73 (2015) 1-8, doi:http://dx. doi.org/10.1093/femspd/ftu011.
[36] Portuguese Directorate-General of Health, Programa Nacional de Vacinação, Norma Da Direção Geral Da Saúde, 2017, pp. 1. http://www.dgs.pt/upload/ membro.id/ficheiros/i018596.pdf.

[37] B. Blázquez, A. Fresco-Taboada, M. Iglesias-Bexiga, M. Menéndez, P. García, PL3 amidase, a tailor-made lysin constructed by domain shuffling with potent killing activity against pneumococci and related species, Front. Microbiol. 7 (2016) 1-13, doi:http://dx.doi.org/10.3389/fmicb.2016.01156.

[38] N. Bustamante, N.E. Campillo, E. García, C. Gallego, B. Pera, G.P. Diakun, J.L. Sáiz, P. García, J.F. Díaz, M. Menéndez, Cpl-7, a lysozyme encoded by a pneumococcal bacteriophage with a novel cell wall-binding motif, J. Biol. Chem. 285 (2010) 33184-33196, doi:http://dx.doi.org/10.1074/jbc.M110.154559.

[39] R. Díez-Martínez, H. De Paz, N. Bustamante, E. García, M. Menéndez, P. García, Improving the lethal effect of Cpl-7, a pneumococcal phage lysozyme with broad bactericidal activity, by inverting the net charge of its cell wall-binding module, Antimicrob. Agents Chemother. 57 (2013) 5355-5365, doi:http://dx. doi.org/10.1128/AAC.01372-13.

[40] J. Varea, B. Monterroso, J.L. Sáiz, C. López-Zumel, J.L. García, J. Laynez, P. García, M. Menéndez, Structural and thermodynamic characterization of Pal, a phage natural chimeric lysin active against Pneumococci, J. Biol. Chem. 279 (2004) 43697-43707, doi:http://dx.doi.org/10.1074/jbc.M407067200.

[41] R. Diez-Martinez, H.D. De Paz, E. Garcia-Fernandez, N. Bustamante, C.W. Euler, V.A. Fischetti, M. Menendez, P. Garcia, A novel chimeric phage lysin with high in vitro and in vivo bactericidal activity against Streptococcus pneumoniae, J. Antimicrob. Chemother. 70 (2015) 1763-1773, doi:http://dx.doi.org/10.1093/ jac/dkv038.

[42] J.M. Sanz, J.L. García, Structural studies of the lysozyme coded by the pneumococcal phage $\mathrm{Cp}-1$. Conformational changes induced by choline, Eur. J. Biochem. 187 (1990) 409-416, doi:http://dx.doi.org/10.1111/j.1432-1033.1990. tb15319.x.

[43] M.S. Levander, E. Grodzinsky, Variation in normal ear temperature, Am. J. Med. Sci. 354 (2017) 370-378, doi:http://dx.doi.org/10.1016/j.amjms.2017.05.013.

[44] M.T. Wezyk, A. Makowski, pH of fluid collected from middle ear in the course of otitis media in children, Otolaryngol. Pol. 54 (2000) 131-133. http://www. ncbi.nlm.nih.gov/pubmed/10961068.

[45] B. Maestro, A. González, P. García, J.M. Sanz, Inhibition of pneumococcal choline-binding proteins and cell growth by esters of bicyclic amines, FEBS J. 274 (2007) 364-376, doi:http://dx.doi.org/10.1111/j.1742-4658.2006.05584.x.

[46] L. Hall-Stoodley, F.Z. Hu, A. Gieseke, L. Nistico, D. Nguyen, J. Hayes, M. Forbes, D. P. Greenberg, B. Dice, A. Burrows, P.A. Wackym, P. Stoodley, J.C. Post, G.D. Ehrlich, J.E. Kerschner, Direct detection of bacterial biofilms on the middle-ear mucosa of children with chronic otitis media, JAMA 296 (2006) 202, doi:http:// dx.doi.org/10.1001/jama.296.2.202.

[47] M. Hoa, S. Tomovic, L. Nistico, L. Hall-Stoodley, P. Stoodley, L. Sachdeva, R. Berk, J.M. Coticchia, Identification of adenoid biofilms with middle ear pathogens in otitis-prone children utilizing SEM and FISH, Int. J. Pediatr. Otorhinolaryngol. 73 (2009) 1242-1248, doi:http://dx.doi.org/10.1016/j.ijporl.2009.05.016.

[48] R. Vázquez, P. García, Synergy between two chimeric lysins to kill Streptococcus pneumoniae, Front. Microbiol. 10 (2019) 1-10, doi:http://dx.doi.org/10.3389/ fmicb.2019.01251.

[49] G. Resch, P. Moreillon, V.A. Fischetti, A stable phage lysin (Cpl-1) dimer with increased antipneumococcal activity and decreased plasma clearance, Int. J. Antimicrob. Agents 38 (2011) 516-521, doi:http://dx.doi.org/10.1016/j. ijantimicag.2011.08.009. 